\title{
Preparation and evaluation of combined inactivated vaccine containing rota, corona viruses, Escherichia coli bacterin and Clostridium perfringens type Ctoxoid (Entero-4)
}

\author{
A. M. Daoud ${ }^{1}$, R. A. Diab ${ }^{1}$, S. M. Aboul Saoud', \\ S. M. Zeidan ${ }^{1}$, F. F. Zaki ${ }^{2}$ \\ ${ }^{1}$ Veterinary Serum and Vaccine Research Institute, Abbassia, Cairo, Egypt \\ ${ }^{2}$ Central Laboratory for Evaluation of Veterinary Biologics, Abbassia, Cairo, Egypt
}

\begin{abstract}
A conclusive study was conducted for preparation and evaluation of combined inactivated entero-4 vaccine containing bovine rotavirus (BRV), bovine coronavirus (BCV), E. coli $\mathrm{K}_{99}$ and toxoid of $C$. perfringens type "C".

Laboratory and field evaluations were conducted on laboratory animals, calves and late pregnant cows with monitoring the active and passive antibodies in vaccinated cows and their offspring respectively. Laboratory evaluation proved purity, safety and high efficacy of the vaccine without interference between different vaccine ingredients. Field evaluation gave satisfactory results when pregnant cows vaccinated at late stage of pregnancy with high neutralizing antibody titers against BRV, BCV and $C$. perfringens as well as high $E$. coli agglutinating titers. Maternal immunity passively protected offspring during the critical period of age and remained protected till the end of sampling time ( $30^{\text {th }}$ day post parturition).
\end{abstract}

Diarrheal diseases are the most important causes of death especially during the early few weeks of life in which a considerable number of newly born animals could be lost (Acres et al., 1977).

Neonatal calf diarrhoea has a complex etiological agents (Radostitis, 1991), as bovine rotavirus (BRV) and bovine coronavirus (BCV), being the most dominant causative agent in combination with other bacterial agents as enterotoxigenic E. coli (Snodgrass et al., 1986 and Saif and Theil, 1990), and Clostridium perfringens type $\mathrm{C}$ that cause a highly fatal hemorrhagic enteritis among calves less than 10 days of age (Niilo, 1980 and Quigley et al., 1995).

Previous studies proved that the percentage incidence of pathogens affecting neonates in Egypt were $37.3 \%$ for BRV, $18.2 \%$ for BCV and $25.4 \%$ for E. coli (Farid et al., 1992). Clostridia as well as other non- infectious causes including; environment, management, hygiene and nutritional factors were represented $19.1 \%$ of neonatal affections (Perk et al., 2000).

Since, infection repeatedly occurs at birth, it is almost impossible to actively immunize them prior to exposure to virulent field viruses or bacteria.Therefore, the best way to reduce economic losses in calves is the active immuniz- ation of pregnant dams during late stage of pregnancy to increase the level of immunoglobulins which are passively transferred to calves (Saif et al., 1983). It is postulated that colostral antibodies in the intestine can neutralize field viruses and bacteria and guard against diseases. Depending on the balance between the infective dose and the antibody titers, animals can be infected or developed immunity without showing clinical diseases.

The previously mentioned data about diarrhoea in combination with the dramatic economic losses made the development of effecious inactivated vaccine containing the most destructive viral and bacterial agents is necessary. Thus, the present work was planned to widen the locally prepared enter-3 vaccine (Daoud et al., 2003) that contains bovine rota, coronaviruses and E. coli $\mathrm{K}_{99}$ vaccine by incorporation of $C$. perfringens type $\mathrm{C}$ toxoid.

\section{Material and Methods}

Viruses. Local isolates BRV and reference strain of BCV was used for preparation and evaluation of the vaccine. The viruses were kindly supplied by the Central Laboratory for Evaluation of Veterinary Biologics.

Bacteria. Reference strain of enterotoxigenic $E$. coli $\mathrm{K}_{99}$ strain was kindly supplied from Animal Reproduction Research Institute, Giza, Egypt. 
Reference strain of toxigenic C. perfringens type C was supplied from med.l school, Edinburgh Univ., UK.

Hyperimmune sera. Specific hyperimmune sera against BRV, BCV, E. coli and C. perfringens type Cwere kindly supplied from the Central Laboratory for Evaluation of Veterinary Biologics, Abbassia, Cairo, Egypt.

Vaccine preparation. Binary ethyleneimine (BEI) inactivated rota and coronaviruses and formalin inactivated E. coli and C. perfringens type $\mathrm{C}$ were adjuvanted with aluminium hydroxide according to the method described by (Kasem et al., 1999; Daoud et al., 2003 and Fayez and Zeidan, 2004).

Evaluation of the prepared vaccine.

Sterility test. Different steps of vaccine preparation which includes viruses or bacterial propagation for seed production, fluid harvestion, fluid inactivation and final gel adjuvanted vaccinel product were subjected to srerility test according to the method described by British Veterinary Pharmacopoeia (1993).

Safety test. 50 adult Swiss albino mice were divided into 5 groups to study the safety of the prepared inactivated vaccines, which include monovalent E. coli $\mathrm{K}_{99}, C$. perfringens type $\mathrm{C}$, bivalent rota/corona vaccine and polyvalent rota/coronaviruses, E. coli $\mathrm{K}_{99}$ and C. perfringens type $\mathrm{C}$ vaccine. Each mouse in each group inoculated intraperitoneally with a dose of $0.2 \mathrm{ml}$ of each vaccine, 10 mice were kept as nonvaccinated control.

Entero-4 vaccine was also tested for its safety in applicant host by inoculation of two susceptible calves intramuscularly with $50 \mathrm{ml}$ (10 vaccinal doses). Inoculated and control animals were kept under observation for 10 days.

Efficacy tests.

A. In calves: Efficacy of the prepared monovalent $C$. perfringens type $\mathrm{C}$, entero-3 (BRV, BCV and E. coli) and entero-4 (BRV, $\mathrm{BCV}, E$. coli and $C$. perfringens type C) vaccines were conducted in three calf groups $A$, $\mathrm{B}$ and $\mathrm{C}$ respectively, five calves each. The vaccination was conducted through $\mathrm{i} / \mathrm{m}$ inoculation ( $2 \mathrm{ml}$ of monovalent, $4 \mathrm{ml}$ of enter-3 and $5 \mathrm{ml}$ of entero-4) with two doses at three weeks interval. Calves were bled at 0, 1, 2, 4, 6 and 8 weeks post vaccination, sera were tested for both neutralizing antibodies of BRV, BCV and $C$. perfringens and agglutinating $E$. coli antibodies according to the methods described by (Collins et al., 1988; European Pharmacopoeia, 2001 and Daoud et al., 2003).

B. In pregnant cows. Fifteen pregnant Holstein cows in private dairy herds in Alexandria Governorate were assigned into two groups. Group I (12 cows) was inoculated by deep intramuscular injection, at one week before drying-off or $8-12$ weeks before calving with 5 $\mathrm{ml}$ of the combined vaccine. Two weeks later, cows were boostered with identical inoculum. Group II (3 cows) was left as non-vaccinated control.

Serum samples were collected from different tested cows group at both vaccination, and parturition time. First milking colostrum was obtained from tested cows and treated as described by (Saif et al., 1983).

Sera of newly born calves were also collected at $1^{\text {st }}, 2^{\text {nd }}, 3^{\text {rd }}$ and $4^{\text {th }}$ weeks post parturition. Both serum and colostral samples were subjected for serum neutralization test (Dauvergene et al., 1983), antitoxin neutralization test (Gadalla et al., 1971), and microagglutination test (Collins et al., 1988) for evaluation of the immunogenicity for rota/ coronaviruses, $C$. perfringens type $\mathrm{C}$ and $E$. coli $\mathrm{K}_{99}$ respectively.

\section{Results and Discussion}

Neonatal diarrhoea is one of the most important problems of cattle industry allover the world (Radostitis, 1991), including Egypt (Shalaby et al., 1981 and Perk et al., 2000). The present situation in Egypt dictates development of control and preventive measures through preparation and application of a highly effective conclusive vaccine containing most destructive viral and bacterial etiological agents e.g. BRV, $\mathrm{BCV}, E$. coli and C. perfringens type C. As the hazard of calf loss is usually expected during the first two weeks of life (Perk et al., 2000), thus the correct protection should be directed to active immunization of late pregnant cow dams to amplifying the magnitude of immunoglobulins in their colostrum nd milk (Myer, 1980). The preliminary studies for preparation of combined gel adjuvanted inactivated vaccine containing BEI inactivated rota/coronaviruses, and formalin inactivated $E$. coli $\mathrm{K}_{99}$ and $C$. perfringens type $\mathrm{C}$

(entero-4), gave satisfactory results regarding sterility and complete neutralization with respective reference antisera. Also neither aerobic nor anaerobic bacterial growth was seen in the inoculated media and remained 
Table (1): Serum neutralizing antibody titers against bovine rota and coronaviruses in calves post vaccination with entero-3 (BRV, BCV and E. coli) and entero-4 (BRV, BCV, E.coli and $C$. perfringens type $\mathrm{C})$ vaccines.

\begin{tabular}{|c|c|c|c|c|c|c|c|c|c|c|c|c|c|c|}
\hline \multirow{3}{*}{ 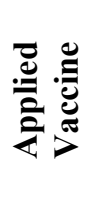 } & \multirow{3}{*}{ 总 } & \multirow{3}{*}{ 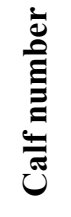 } & \multicolumn{12}{|c|}{$\log _{10}$ Rota, Corona antibody titers at weeks PV } \\
\hline & & & \multicolumn{2}{|c|}{ 0 } & \multicolumn{2}{|c|}{1} & \multicolumn{2}{|c|}{2} & \multicolumn{2}{|c|}{4} & \multicolumn{2}{|c|}{6} & \multicolumn{2}{|c|}{8} \\
\hline & & & $\mathbf{R}$ & C & $\mathbf{R}$ & C & $\mathbf{R}$ & C & $\mathbf{R}$ & C & $\mathbf{R}$ & C & $\mathbf{R}$ & C \\
\hline \multirow{5}{*}{ 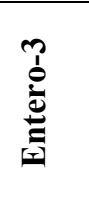 } & \multirow{4}{*}{ B } & 5 & 0.3 & 0.0 & 0.6 & 0.3 & 0.9 & 0.6 & 1.8 & 1.5 & 2.4 & 2.1 & 2.1 & 2.1 \\
\hline & & 6 & 0.0 & 0.0 & 0.3 & 0.3 & 0.6 & 0.9 & 1.5 & 1.5 & 2.1 & 2.4 & 2.1 & 1.8 \\
\hline & & 7 & 0.3 & 0.0 & 0.6 & 0.3 & 0.6 & 0.9 & 1.8 & 1.8 & 2.7 & 2.7 & 2.4 & 2.4 \\
\hline & & 8 & 0.0 & 0.3 & 0.3 & 0.6 & 0.6 & 0.6 & 1.5 & 1.5 & 2.4 & 2.1 & 2.1 & 2.1 \\
\hline & \multicolumn{2}{|c|}{ Mean } & 0.15 & 0.075 & 0.45 & 0.375 & 0.675 & 0.75 & 1.65 & 1.575 & 2.4 & 2.325 & 2.175 & 2.1 \\
\hline \multirow{5}{*}{ 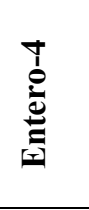 } & \multirow{5}{*}{ C } & 9 & 0.3 & 0.0 & 0.6 & 0.3 & 0.9 & 0.9 & 1.8 & 1.8 & 2.4 & 2.4 & 2.1 & 2.1 \\
\hline & & 10 & 0.3 & 0.0 & 0.6 & 0.6 & 0.9 & 0.9 & 1.8 & 1.8 & 2.7 & 2.7 & 2.4 & 2.4 \\
\hline & & 11 & 0.3 & 0.3 & 0.3 & 0.6 & 0.6 & 0.9 & 1.5 & 1.5 & 2.4 & 2.4 & 2.4 & 2.1 \\
\hline & & 12 & 0.0 & 0.3 & 0.3 & 0.3 & 0.6 & 0.6 & 1.5 & 1.5 & 2.4 & 2.1 & 2.1 & 2.1 \\
\hline & & & 0.225 & 0.15 & 0.45 & 0.45 & 0.75 & 0.825 & 1.65 & 1.65 & 2.475 & 2.4 & 2.25 & 2.175 \\
\hline
\end{tabular}

Table (2): $E$. coli $\mathrm{K99}$ microagglutination antibodies in calf sera post vaccination with entero-3 (BRV, BCV and E. coli) and entero-4 (BRV, BCV, E. coli and $C$. perfringens $\mathrm{C}$ ) vaccines.

\begin{tabular}{|c|c|c|c|c|c|c|c|c|}
\hline \multirow{2}{*}{$\begin{array}{l}\text { Applied } \\
\text { vaccine }\end{array}$} & \multirow{2}{*}{ Group } & \multirow{2}{*}{$\begin{array}{l}\text { Calf } \\
\text { No. }\end{array}$} & \multicolumn{6}{|c|}{$\begin{array}{l}\text { E. coli K99 microagglutination antibody tites at weeks post } \\
\text { vaccination }\end{array}$} \\
\hline & & & 0 & 1 & 2 & 4 & 6 & 8 \\
\hline \multirow{5}{*}{ Entero-3 } & \multirow{4}{*}{ B } & 5 & 4 & 16 & 32 & 128 & 512 & 1024 \\
\hline & & 6 & 4 & 16 & 32 & 128 & 512 & 1024 \\
\hline & & 7 & 2 & 32 & 64 & 128 & 512 & 1024 \\
\hline & & 8 & 2 & 32 & 128 & 256 & 1024 & 2048 \\
\hline & \multicolumn{2}{|c|}{ Mean } & 3 & 24 & 64 & 160 & 640 & 1280 \\
\hline \multirow{5}{*}{ Entero-4 } & \multirow{4}{*}{ C } & 9 & 4 & 32 & 64 & 128 & 512 & 1024 \\
\hline & & 10 & 4 & 32 & 128 & 256 & 1024 & 1024 \\
\hline & & 11 & 4 & 16 & 64 & 128 & 512 & 1024 \\
\hline & & 12 & 2 & 16 & 32 & 128 & 512 & 2048 \\
\hline & \multicolumn{2}{|c|}{ Mean } & 3.5 & 24 & 72 & 160 & 640 & 1280 \\
\hline
\end{tabular}

Table (3): Neutralizing $C$. perfringens beta antitoxin titres in calves post vaccination with monovalent and polyvalent vaccine (entero-4).

\begin{tabular}{|c|c|c|c|c|c|c|c|c|}
\hline \multirow{2}{*}{ Applied vaccine } & \multirow[t]{2}{*}{ Group } & \multirow[t]{2}{*}{ Calf No. } & \multicolumn{6}{|c|}{$\begin{array}{l}\text { C. perfrigens beta antitoxin } \mathrm{IU} / \mathrm{ml} \text { titres } \\
\text { post vaccination (weeks) }\end{array}$} \\
\hline & & & 0 & 1 & 2 & 4 & 6 & 8 \\
\hline \multirow{4}{*}{$\begin{array}{c}\text { Monovalent } C \text {. } \\
\text { perfringens } \\
\text { vaccine }\end{array}$} & \multirow{4}{*}{ A } & 1 & 0 & 1 & 5 & 25 & 30 & 35 \\
\hline & & 2 & 0 & 2 & 7 & 30 & 30 & 35 \\
\hline & & 3 & 0 & 3 & 4 & 20 & 25 & 25 \\
\hline & & 4 & 0 & 1 & 4 & 20 & 25 & 30 \\
\hline \multirow{6}{*}{ Entero-4 } & \multicolumn{2}{|c|}{ Mean } & 0 & 1.75 & 5 & 23.75 & 27.5 & 31.25 \\
\hline & \multirow{4}{*}{ C } & 9 & 0 & 2 & 4 & 25 & 30 & 35 \\
\hline & & 10 & 0 & 2 & 6 & 30 & 30 & 35 \\
\hline & & 11 & 0 & 2 & 5 & 20 & 30 & 30 \\
\hline & & 12 & 0 & 1 & 5 & 20 & 30 & 35 \\
\hline & \multicolumn{2}{|c|}{ Mean } & 0 & 1.75 & 5 & 23.75 & 30 & 33.75 \\
\hline
\end{tabular}


Table (4): Neutralizing rota and corona antibody titres in pregnant cows' sera, colostrums and their pffsprings sera post vaccination with entero-4 (BRV, BCV, E. coli K99 and C. perfringens type "C") vaccine.

\begin{tabular}{|c|c|c|c|c|c|c|c|c|c|c|c|c|c|c|}
\hline \multirow{4}{*}{ 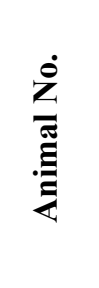 } & \multicolumn{14}{|c|}{$\log _{10}$ Neutralizing antibody titres in } \\
\hline & \multicolumn{4}{|c|}{ Pregnant cow's sera at } & \multirow{2}{*}{\multicolumn{2}{|c|}{ Colostrum }} & \multicolumn{8}{|c|}{ Offspring's sera at weeks Post parturition } \\
\hline & \multicolumn{2}{|c|}{$\begin{array}{c}\text { Vaccination } \\
\text { time }\end{array}$} & \multicolumn{2}{|c|}{ Parturition time } & & & \multicolumn{2}{|c|}{1} & \multicolumn{2}{|c|}{2} & \multicolumn{2}{|c|}{3} & \multicolumn{2}{|c|}{4} \\
\hline & $\mathbf{R}$ & $\mathbf{C}$ & $\mathbf{R}$ & $\mathbf{C}$ & $\mathbf{R}$ & $\mathbf{C}$ & $\mathbf{R}$ & $\mathbf{C}$ & $\mathbf{R}$ & $\mathbf{C}$ & $\mathbf{R}$ & $\mathbf{C}$ & $\mathbf{R}$ & $\mathbf{C}$ \\
\hline 1 & 0.6 & 0.0 & 2.4 & 2.1 & 2.7 & 2.4 & 2.1 & 2.1 & 1.8 & 1.8 & 1.5 & 1.5 & 1.2 & 1.2 \\
\hline 2 & 0.3 & 0.0 & 2.1 & 2.4 & 2.4 & 2.4 & 1.8 & 2.1 & 1.5 & 1.8 & 1.2 & 1.2 & 0.9 & 0.9 \\
\hline 3 & 0.6 & 0.3 & 2.4 & 2.4 & 2.4 & 2.7 & 1.8 & 1.8 & 1.5 & 1.5 & 1.2 & 1.5 & 1.2 & 0.9 \\
\hline 4 & 0.9 & 0.6 & 2.1 & 2.1 & ND & ND & 1.8 & 1.8 & 1.8 & 1.5 & 1.5 & 0.9 & 1.2 & 0.9 \\
\hline 5 & 0.3 & 0.3 & 2.4 & 2.4 & 2.7 & 2.7 & 2.1 & 2.1 & 1.8 & 1.8 & 1.8 & 1.8 & 1.5 & 1.2 \\
\hline 6 & 0.3 & 0.3 & 2.7 & 2.4 & 2.4 & 2.4 & 1.8 & 2.1 & 1.5 & 1.8 & 1.2 & 1.5 & 1.2 & 1.2 \\
\hline 7 & 0.3 & 0.3 & 2.1 & 2.7 & ND & ND & 1.8 & 2.4 & 1.5 & 2.1 & 1.2 & 1.8 & 0.9 & 1.5 \\
\hline 8 & 0.0 & 0.6 & 2.1 & 2.4 & 2.1 & 2.4 & 1.5 & 2.1 & 1.2 & 1.8 & 0.9 & 1.5 & 0.9 & 1.2 \\
\hline 9 & 0.6 & 0.3 & 2.4 & 2.4 & 2.4 & 2.4 & 2.1 & 1.8 & 1.8 & 1.5 & 1.2 & 1.2 & 1.2 & 0.9 \\
\hline 10 & 0.0 & 0.0 & 2.1 & 2.4 & ND & ND & 1.8 & 1.8 & 1.5 & 1.5 & 1.2 & 1.2 & 1.2 & 1.2 \\
\hline Mean & 0.39 & 0.27 & 2.28 & 2.37 & 2.44 & 2.48 & 1.86 & 2.01 & 1.59 & 1.71 & 1.29 & 1.41 & 1.14 & 1.11 \\
\hline
\end{tabular}

Table (5): $E$. coli microagglutination antibody titers in pregnant cow's sera, colostrums and offspring's sera post vaccination of pregnant cows with polyvalent $\mathrm{BRV}, \mathrm{BCV}, E$. coli $\mathrm{K99}$ and $C$. perfringens type $\mathrm{C}$ vaccine.

\begin{tabular}{|c|c|c|c|c|c|c|c|}
\hline \multirow{3}{*}{ 离 } & \multicolumn{7}{|c|}{ E. coli K99 microagglutination antibody titers in } \\
\hline & \multicolumn{2}{|c|}{ Pregnant cow's sera at } & \multirow{2}{*}{ Colostrum } & \multicolumn{4}{|c|}{ Offspring's sera } \\
\hline & Vaccination time & Parturition time & & 1 & 2 & 3 & 4 \\
\hline 1 & 16 & 1024 & 1024 & 1024 & 1024 & 512 & 512 \\
\hline 2 & 16 & 512 & 1024 & 2048 & 1024 & 512 & 512 \\
\hline 3 & 32 & 1024 & 1024 & 1024 & 1024 & 512 & 256 \\
\hline 4 & 16 & 512 & ND & 1024 & 1024 & 512 & 512 \\
\hline 5 & 16 & 512 & 512 & 1024 & 512 & 512 & 256 \\
\hline 6 & 64 & 1024 & 1024 & 2048 & 1024 & 1024 & 512 \\
\hline 7 & 16 & 512 & ND & 1024 & 512 & 512 & 265 \\
\hline 8 & 8 & 512 & 1024 & 1024 & 512 & 512 & 265 \\
\hline 9 & 16 & 1024 & 1024 & 1024 & 1024 & 512 & 265 \\
\hline 10 & 16 & 1024 & ND & 1024 & 1024 & 512 & 265 \\
\hline Mean & 21.6 & 768 & 950 & 1228.8 & 870.4 & 563.2 & 358.4 \\
\hline
\end{tabular}

sterile for 15 days post inoculation. These results are in harmony with that obtained from animal inoculation tests which confirmed vaccine safety as the inoculated mice and safety tested calves remained clinically normal without deaths or elevation of temperature.

Concerning with serological interference studies between ingredients of entero-3 vaccine (rota, coronaviruses and $E$. coli $\mathrm{K}_{99}$ ) and $C$. perfringens type $\mathrm{C}$ vaccine in calves are represented in (Tables 1-3). Mean neutralizing antibody titre (NAT) against BRV and BCV in entero-3 (group B) and entero-4 (group C) potency tested calves were increased by the $4^{\text {th }}$ week following vaccination to $1.65,1.575$ and $1.65,1.65 \log _{10}$ respectively. Maximal response occurred at the $6^{\text {th }}$ week following the $1^{\text {st }}$ vaccination with a titre of $2.4,2.32$ and 2.475 , 

Table (6): $C$. perfringens beta antitoxins in pregnant cows' sera, colostrums and offspring's sera post vaccination of pregnant cows with entero-4.

\begin{tabular}{|c|c|c|c|c|c|c|c|}
\hline \multirow{3}{*}{ 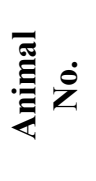 } & \multicolumn{7}{|c|}{ Neutralizing $C$. perfringens beta antitoxin antibody titers in } \\
\hline & \multicolumn{2}{|c|}{ Pregnant cow's sera } & \multirow{2}{*}{ Colostrum } & \multicolumn{4}{|c|}{ Offspring's sera at weeks Post parturition } \\
\hline & Vaccination time & Parturition time & & 1 & 2 & 3 & 4 \\
\hline 1 & 5 & 35 & 40 & 35 & 25 & 15 & 10 \\
\hline 2 & 0 & 35 & 35 & 30 & 20 & 10 & 5 \\
\hline 3 & 0 & 35 & 40 & 30 & 20 & 15 & 10 \\
\hline 4 & 0 & 40 & ND & 30 & 20 & 10 & 5 \\
\hline 5 & 5 & 35 & 35 & 25 & 15 & 10 & 5 \\
\hline 6 & 5 & 40 & 40 & 30 & 20 & 15 & 10 \\
\hline 7 & 0 & 30 & ND & 25 & 15 & 10 & 5 \\
\hline 8 & 0 & 30 & 35 & 25 & 15 & 10 & 5 \\
\hline 9 & 5 & 40 & 40 & 30 & 20 & 10 & 5 \\
\hline 10 & 0 & 30 & ND & 25 & 15 & 10 & 5 \\
\hline Mean & 2 & 35 & 37.5 & 28.5 & 18.5 & 11.5 & 6.5 \\
\hline
\end{tabular}

ND: Not Done

$2.4 \log _{10}$ respectively (Table 1). These results are gone in harmony with that obtained by (Daoud et al., 2003). E. coli $\mathrm{K}_{99}$ microagglutinating titers obtained by entero-3 vaccinated calves (group B) and entero-4 vaccinated calves (group C) are represented in (table 2). It revealed that mean agglutinating titers in groups $\mathrm{B}$ and $\mathrm{C}$ increased by the $4^{\text {th }}$ week post vaccination to 160 agglutinating unit where as maximal titer obtained by the $8^{\text {th }}$ week post vaccination (1280) agglutinating unit. These results indicate that there was no immunological interference between E. coli bacterin and either BRV, BCV or $C$. perfringens type Cfractions in the Inactivated vaccine. These results agree with the findings of (Collins et al., 1988 and Daoud et al., 2003) who reported no serological interference between either rota or coronavirus fractions and the E. coli bacterin.

Concerning $C$. perfringens neutralizing antitoxin (Table 3), the Obtained results proclaimed that the antitoxin titres increased in monovalent vaccinated calves (group A), and entero- 4 vaccinated calves (group C), by the $4^{\text {th }}$ week post vaccinated to $23.75 \mathrm{IU}$ and the maximal titers were obtained by the $8^{\text {th }}$ week where it reached 31.25 and 33.75 IU respectively. Field vaccination of late pregnant cows with entero-4 vaccine causing elicited neutralizing antibodies against BRV, $\mathrm{BCV}$ and antitoxin to $C$. perfringens type $\mathrm{C}$ (Tables 4,6 ). The mean $\log _{10}$ SNAT against BRV and BCV at time of parturition were 2.28 and 2.37 respectively while antitoxin against beta toxoid was $35 \mathrm{IU}$. These results agree with that obtained by (Fleenor and Scott 1983; Daoud et al., 2003 and Fayez and Zeidan 2004) who concluded that field evaluation gave satisfactory results when pregnant cows were vaccinated at late stage of pregnancy with high level of serum neutralizing antibodies against $\mathrm{BRV}, \mathrm{BCV}$ and C. perfringens type C.

The colostrum of vaccinated cows were proven to be very rich with immunoglobulins against different fractions of the entero-4 vaccine as it reached 2.44, $2.48 \log _{10}$ NAT for BRV, BCV; 37.5 IU beta antitoxin titers and 950 E. coli agglutinating titers.

Maternal immunity was monitored in offsprings of entero- 4 vaccinated cows for four weeks post parturition for detection of antibodies to $\mathrm{BRV}, \mathrm{BCV}, E$. coli and antitoxin against $C$. perfringens toxoid (Tables 4- 6). The obtained results proved that the maternal antibody titres in both colostrum and offsprings are highly correlated with the active titers of cows at parturition. These results are agreed with (Daoud et al., 2003 and Fayez and Zeidan 2004).

It conclusion, the prepared vaccine is safe, potent and efficient and can be used for maternal vaccination as it is the only suitable method to amplify maternal immunity since high quality colostrums feeding is the most effective tool for preventing neonatal diarrhoeal diseases.

\section{References}

Acres, S. D.; Sanunders, J. R. and Radostis, O. M. (1977): Acute undiffentited neonatal diarrhoea of beef calves, the prevalence of entero-toxogenic $E$. coli, rotavirus and other enteropathogens in cow calf-herds. Can. Vet. J., 18: 113-121. 
British Veterinary Pharmacopoeia (1993): The Pharmaceutical Press, London.

Collins, N. F.; Halbur, T.; Schwenck, W. H.; Hoogeveen, P.; Pierce, R. L.; Behan, R. W. and Pankratz, D. (1988): Duration of immunity and efficacy of an oil emulsion $E$. coli bacterin in cattle. Am. J. Vet. Res., 49 (5): 674-677.

Daoud, A. M.; Zeidan, S. M.; Wassel, M. S.; Gergis, S. M. and Effat, L. (2003): Evaluation and field application of locally prepared combined inactivated rota/coronaviruses and E. coli K99 (entero-3) vaccine. $7^{\text {th }}$ Sci. Cong., Egypt. Soci. Cattle Dis., Assiut, Egypt, 257-270.

Dauvergene, M. L.; Laporte, G.; Reymoud, P.; Burn S. A. and Espinasse, J. (1983): Vaccination of dams with a combined rotavirus, coronavirus vaccine to protect new born calves against diarrhoea. Proc. $4^{\text {th }}$ Int. Symp. Neonatal diarrhoea, VIDO, Saskatchewan, Canada, pp., 424-432.

European Pharamacopoeia (2001): $4^{\text {th }}$ ed., Council of Europe, 67075 Strasbourg Codex, France.

Farid, A. F.; Saad, M. K. and Kaldas, Y. T. (1992): Causes of mortality of newborn calves in some farms in Egypt. Proc. Sci. Cong., Fac. Vet. Med., Assiut Univ., Egypt, pp. 81-87.

Fayez, M. M. and Zeidan, S. M. (2004): Studies for preparation of combined inactivated vaccine containing rota, coronaviruses and toxoid of Clostridium perfringens type C. The $1^{\text {st }}$ Sci. Conf., Fac. Vet. Med., Moshtohor, Benha, Egypt, pp. 1-4.

Fleenor, W. A. and Scott, G. H. (1983): Quantification of bovine IgG; IgM, and IgA antibodies to Clostridium perfringens beta toxin by enzyme immunoassay. I. Preparturient immunization for enhancement of passive transfer of immunity. Vet. Immun. Immunopath., 4: 579591.

Gadalla, M. S.; Farrag, I. And Dorya, S. (1974): Effect of growth requirement on the improvement of clostridial vaccines. J. Egypt. Vet. Med. Assoc., 34 (1/2): 19-28.

Kassem, I. K. A. and Zeidan, S. M. (1999): The effect of different adjuvant on the immune response of inactivated bovine rotavirus vaccine. Alex. J. Vet. Sci., 3:579-590.

Myers, L. L. (1980): Passive protection of calves against experimentally induced and naturally occurring enteric colibacillosis. Am. J. Vet. Res., 41 (12): 1952-1956.

Niilo, L. (1980): Clostridium perfringens in animal disease. Can. Vet. J., 21: 141-148.

Perk, K.; Moussa, A. A.; Tromp, A. M.; Reda, I. M.; Rafai, M.; Friedman, A.; Farid, A. F.; Gallily, O.; Salah, S. M. and Saif, L. (2000): Neonatal diarrheal disease of dairy cattle in Egypt and Israel. Israel Vet. Med. Assoc., 55 (1): 1-7.

Quigley, J. D.; Martin, K. R.; Bemis, D. A.; Potgieter, L. N. D.; Reinemerger, C. R.; Rohrboch, B. W.; Dowlen, H. H. and Lamar, K. C. (1995): Effects of housing and colostrums feeding on serum immunoglobulins, growth and fecal scours of Jersey calves. J. Dairy Sci., 78: 893-901.

Radostits, O. M. (1991): The role of management and the use of vaccines in the control of acute undifferentiated diarrhoea of newborn calves. Can. Vet., 32: 155-159.

Saif, L. J. and Theil, K. W. (1990): Viral diarrhoea of man and animals. Boca Raton, FI. CRC Press. Saif, I. J.; Redman, D. R.; Smith, K. L. and Theil, K. W. (1983): Passive immunity to bovine rotavirus in new born calves fed colostrums supplemented from immunized or nonimmunized cow. Infect. Immun., 411: 1118-1131.

Shalaby, M. A.; Saber, M. S. and El-Karmany, R. M. (1981): Rotavirus infection associated with diarrhoea in calves. Egypt. Vet. Res. Comm., 5: 165-170.

Snodgrass, D. R.; Terzolo, H. R. and Sherwood, D. (1986): Aetiology of diarrhoea in young calves. Vet. Res., 119: 31-34. 